\title{
Determinants of Farmers Adaptation to Climate Change. A Case from Nawalparasi District of Nepal
}

\author{
Jeevan Lamichhane ${ }^{1 *}$, Durga Bahadur RanaBhat ${ }^{1}$, Ankit Koirala ${ }^{2}$, Dipesh Shrestha ${ }^{3}$ \\ ${ }^{1}$ Regional Agricultural Research Station, Lumle, Nepal \\ ${ }^{2}$ Institue of Agriculture and Animal Science, Rampur, Chitwan, Nepal \\ ${ }^{3}$ District Agricultural Development Office, Nawalparasi, Nepal
}

A R T I C L E I N F O

Article history:

Received 16 January 2016

Accepted 13 May 2016

Available online, ISSN: 2148-127X

Keywords:

Climate change

Adaptation

Logit model

Probability

Farmers

${ }^{*}$ Corresponding Author:

E-mail: jeevanlamichhane7@gmail.com

\section{A B S T R A C T}

A field survey was conducted to study the factor that determines farmers' decisions to adapt to climate change in Deurali and Agyouli V.D.Cs of Nawalparasi District. Altogether 180 household, 90 from each V.D.C were selected randomly for the study. A logit regression model was employed in the study. However, in order to measure the magnitude of the impact of the explanatory variables on the decision of the farmer to adapt to climate change marginal effects were computed. The study uses a binary dependent variable taking the value 1 if the farmer adapted to climate change and 0 otherwise. A farmer is considered to have adapted to climate change if he/she has employed at least one of the adaptation strategies such as early and late planting, use of drought resistant crops, zero tillage operation, crop diversification, use of mulching and composting of weeds to control water loss and conserving moisture in the field. This current research considers the following as potential factors determining farmers' decisions to adapt to climate change; economically active members, education of the household head, farm size, annual cash earnings, access to credit, training and extension. Findings reveal that these factors influence farmers' decisions to adapt to climate change in Nawalparasi District and marginal effects computed showed that per unit increase in these variables increased the probability of practicing different adaptation strategies by $4.3 \%, 31.4 \%, 3 \%, 1.5 \%, 17 \%, 66 \%$ respectively. The log likelihood was computed to be 43.45. Psuedo. $\mathrm{R}^{2}$ was calculated to be $39 \%$.

\section{Introduction}

Climate change is a pertinent issue affecting the livelihoods and food security in both developing and developed countries. Food and Agricultural Organization (FAO), 2008 argues that many countries worldwide are facing food crises due to conflict and disasters, while food security is being adversely affected by many factors including droughts and floods linked to climate change. Climate change in the form of higher temperatures, uncertainty in rainfall reduces crop yields and threatens food security in low income based economies (Maharjan et al., 2009). A cross-sectional study Nepal reveals that the topography generally progresses from altitudes of less than $100 \mathrm{~m}$ in the southern plain, up to more than $8,000 \mathrm{~m}$ peaks in the north. Agriculture is the mainstay of the economy, providing livelihoods for over 80 percent of the population in Nepal. Nepal also has one of the highest population densities in the world with respect to cultivable land (MOPE, 2000). Shrestha et al., 1999 found that average temperature increase was recorded as $0.06^{\circ} \mathrm{C}$ per year and that in Terai and Himalayas was $0.04^{\circ} \mathrm{C}$ and $0.08^{\circ} \mathrm{C} /$ year respectively. Increase in temperature cause more damage on agricultural sectors in Terai region and will be more favorable to agriculture in the hills and mountains (Schmidhuber and Tubiello, 2007).
In general, temperature increase will reduce yields and quality of food-crops thereby exacerbating vulnerability in food supply. Similarly, changes in precipitation patterns i.e., intensive rain concentrated in a particular month has a devastating effect on crop production (Abrol \& Ingram, 1996). Average minimum and maximum temperature of the study sites is $5^{\circ} \mathrm{C}$ and $38^{\circ} \mathrm{C}$ respectively. Mean precipitation of the area is $2145 \mathrm{~mm}$ per year. The soil in the District is heavy loamy soils. Farming in the study site is rainfed type.

Mostly the poor, women and marginalized communities face the impact of climate change. The populations who rely on agriculture as their main source of livelihood are impacted the most by climate change. Real adaptation in the communities has not yet happened (Smit and Burton, 1999). Even with the preparation of adaptation plans, communities seem to be planning to respond to the short term variability of climate change. The coping strategy adopted has not helped them to deal with extreme events. The socio-economic status of the household is not enough to respond well to the impact of climate change. As majority of the population are below poverty line and facing problem of acute shortage of food 
and access to services, the capacity to adapt is very limited.

Crop diversification, zero tillage, mulching, water Harvesting, plastic tunnelling, use of mulching and composting of weeds to control water loss and conserving moisture are some of the way for communities to cope with the climate change in the study site (District Agriculture Development Office, Nawalparasi, 2011). There are number of factors that govern the farmers to adopt the coping mechanism. This study examines the different factors that govern the decision of farmers to adopt the coping mechanism of climate change.

\section{Materials and Methods}

A household survey was conducted in Nawalparasi district where 180 farmers were randomly sampled from four farming communities of two V.D.Cs in the Nawalparasi district of the Western Development Region in Nepal. Structured and unstructured questionnaires about adaptation and the barriers to adaptation were also posed. The dependent variable is binary choice whether to adopt or not while the explanatory variables includes:

Economically active members, education, farm size, annual cash earning, access to credit, training and extension.

Binary choice models are commonly used when the farmer faces two choices of whether to adopt or not. Kalyabara, 1999 argued that the use of probability models is conceptually preferable to conventional linear regression models. This is because the logit and probit models are superior to the linear probability model (LPM) in that while estimates in the LPM are unbiased, the standard errors are usually biased and the probabilities lie outside the conventional 0 and 1 range. Ordinary least square method cannot be used in such studies as it ignores the discreteness of the dependent variable. In this study the logit model will be selected because of its simplicity over the probit model but still meeting the objective of the study. Fosu-Mensah et al.,(2010) informs a logit model analyses the relationship between a binary dependent variable and a set of independent variables. Several studies have used this method to study farmers adaptation to climate change (Seo and Mendelsohn, 2006). The logit model uses a logistic cumulative distribution function to estimate probabilities (Apata et al., 2009). The logit function is presented as follows:

$$
\begin{aligned}
& \Pi=\varepsilon^{\circledR \Xi} / 1+\varepsilon^{\circledR \Xi} \\
& 1-\Pi=1-\left(\varepsilon^{\circledR \Xi} / 1+\varepsilon^{\circledR \Xi}\right)=1 / 1+\varepsilon^{\circledR \Xi}
\end{aligned}
$$

Where;

$\Pi$ is the probability of success or failure given ${ }_{i}$

$\varepsilon$ denotes the base of natural logarithms, which is approximately equal to 2.718

${ }_{i}^{\Xi}$ represents the $i^{\text {th }}$ independent variables; and

${ }^{\circledR}$ represents the vectors of parameters to be estimated.

The logit model could be written in terms of odds and $\log$ of odds ratios to enable comprehension of the interpretation of the coefficients (Hosmer and Lemeshew,1989). Al-Karablieh (2009) said that this odds ratio is a linear function of the independent variables. From equation explained earlier the odds ratio for a logit model is given by $\mathrm{P} / 1-\mathrm{P}$. This measures the probability that $\mathrm{Y}=1$ relative to the probability that it is zero.

The general form of the logit model can be expressed as follows;

$$
\begin{aligned}
& \operatorname{Prob}(Y=1)=F\left(\beta^{\prime} X\right) \\
& \operatorname{Prob}(Y=0)=1-F\left(\beta^{\prime} X\right)
\end{aligned}
$$

Where;

$i$ is the observed response for the $i^{\text {th }}$ observation of the response variable $\mathrm{Y}$.

$\mathrm{Yi}=1 \mathrm{Y}$ for a farmer who adapts to climate change

$\mathrm{Yi}=0 \mathrm{Y}$ for a farmer did not adapt to climate change

$\mathrm{X}$ is a set of independent variables that determine the farmer's probability to adapt to climate change.

These include economically active members, education, farm size, Annual cash earning, access to credit, training and extension. The data is analysed using the STATA 10 statistical package.

The way a positive and significant variable is interpreted the variable has a higher chance of being in that choice group relative to the reference group. This means that changes in the variable will increase the probability of a farmer to adapt to climate change. A negative and significant sign will mean that the probability of a farmer adapting to climate change is lower than that of the reference point.

\section{The Marginal Effects and Predicted Probabilities}

The estimated coefficients only show the direction of effects of independent variables on the dependent variables and show neither the magnitude nor probabilities; marginal effects are instead used to interpret the effects of independent variables on the probabilities. In order to measure the magnitude of the impact of the explanatory variables on the decision of the farmer to adapt to climate change marginal effects are computed.

\section{Variables Used in the Logit Regression Model}

Table 1 describes the variables used in the logit model. The variables used in the logit regression model were economically active members (16-59), education, farm size, annual cash earning, credit, training and extension. Economically active members (16-59) determine the choice of adaptation and decision to adapt. Greater number of years of education of the household head is expected to adapt against the climate change. Farm size of the household head also determines the adaptation for climate change. Generally farmers with larger farm size are expected to adapt than the farmers with smaller farms size. Household with greater annual cash earnings are expected to adapt faster than with low household cash earning. Farmers with access to credit are supposed to adapt against the climate change. Training and extension facilities increase the probabilities of adapting the impact of climate change. 
Table 1 Variables used in the logit regression model

\begin{tabular}{|c|c|c|c|}
\hline Variables & Description & Unit & Expected sign \\
\hline $\begin{array}{l}\text { Economically active } \\
\text { members }\end{array}$ & $\begin{array}{l}\text { Number of economically active(16-59years) family } \\
\text { members in the household }\end{array}$ & Number & + \\
\hline Education & Education of the household head & Year & + \\
\hline Farm size & Total size of cultivated land & ha & + \\
\hline HH annual cash earning & Annual household cash earning & Nepali Rs & + \\
\hline Credit & $\begin{array}{l}\text { Whether farmer have accessed to credit or not in } \\
\text { reasonable interest rate }(1 / 0)\end{array}$ & $\begin{array}{l}=1 \text { if access; } 0= \\
\text { otherwise }\end{array}$ & + \\
\hline Training and extension & $\begin{array}{l}\text { Whether farmers received training from different } \\
\text { governmental and non-governmental organization } \\
\text { about climate change adaptation strategies }(1 / 0)\end{array}$ & $\begin{array}{l}=1 \text { if farmers received } \\
\text { training and extension; } \\
0=\text { otherwise }\end{array}$ & + \\
\hline
\end{tabular}

\section{Results and Discussions}

\section{Paired Sample Test on Impact of Climate Change}

Analysing the data by paired sample test, there seems a significant impact of climate change (see Table 2). The value of mean difference is 1.128 which clearly indicates that there is a significant effect climate change. The correlation coefficient is found to be 0.588 . Also the $p$ value of the effect on the production of wheat is 0.037 which shows it is significant at $5 \%$ level of significance. The correlation coefficient is found to be 0.588 .

Table 2 Paired sample test on impact of climate change*

\begin{tabular}{l|l}
\hline Mean difference & 1.128 \\
Standard deviation of mean difference & 4.61728 \\
Standard error mean & 0.52280 \\
$\mathrm{t}-$ value & 2.127 \\
Degree of freedom & 79 \\
Sig(2- tailed) & $0.037 * *$ \\
Correlation & 0.588 \\
\hline
\end{tabular}

*Source: Field Survey, 2012; **Significance at $5 \%$ level of Significance

\section{Statistical Description}

Table 3 describes the mean value of the dependent and independent variables used in the model. Average number of economically active family members in the family is 3.35. The mean educational experience of the respondent in the study area is found to be $4.4 \mathrm{yrs}$. The average farm size of the respondents is 0.52 ha. The average annual cash earning of the household is found to be 68.26 thousand. The mean of the binary dependent variable credit and training and extension is found to be 0.4125 \& 0.425 respectively. Psuedo $\mathrm{R}^{2}$ is calculated to be $39 \%$ (see Table 5).

Table 3 Statistical description of the different variables used in logit model*

\begin{tabular}{ll|cc}
\hline \multicolumn{1}{c|}{ Variables } & Mean & SE \\
\hline Adaptation strategies & 0.58 & 0.56 \\
Number of economically active & 3.35 & 0.20 \\
family members & & \\
Education & & 4.4 & 0.47 \\
Farm size & 0.52 & 1.02 \\
Annual household & cash & 68.26 & 48.731 \\
earning('000) & & \\
Credit & & \\
Training and extension & & 0.4125 & 0.56 \\
\hline
\end{tabular}

*Source: Field Survey, 2012; SE: Standard error

\section{Results of Logit Regression}

Education: Education is statistically significant at $5 \%$ level of significance as shown by a p-value of 0.0038 (Table 4). The coefficient is positive implying that education have a strong influence in adapting to climate change. Increasing the number of years of education of the farmers increases the probability of adapting to climate change in Nawalparasi district district by $31.4 \%$ (see Table 4). This implies that as farmers in Nawalparsi district acquire more education, their probability of adapting to climate change increases. Thus farmers in Nawalparasi have a general appreciation of the benefits of adapting to climate change due to education. Deressa et al., (2010) found a positive relationship between education and adaptation to climate change in Ethiopia. In addition Aris (2010) also found that farmers who have university education are more likely to respond to climate change than farmers who have primary education.

Economically active members:This variable has a positive coefficient implying that larger families tend to adapt to climate change more than smaller families. Farming in Nawalparsi district is mostly labour intensive and farmers tend to employ labour intensive adaptation strategies such as conservation farming. The results show that increasing a farm household by one more member increases the probability of adapting to climate change by about $4.3 \%$ (see Table 4). This implies that the bigger the family size the higher the probability of adapting to climate change. These results are in support of Gbetibouo (2009) who found that family household size enhances the farmer's adaptive capacity in the Limpopo Basin of South Africa. However, they are contrary to findings by Apata et al., (2009) who found that increase in household size reduces the probability of a farmer adapting to climate change.

Farm size:The bigger the size of the farm, the greater the proportion of land allocated for modern crop varieties the adaptation strategies that the farmer is likely to adopt (Gunjal, 2008). The bigger the farm size, the more likely the farmer is to adopt suitable strategies. The expected sign is positive and the variable will be continuous recording the number of hectares of the farm. This variable has a positive coefficient implying that addition of unit of hectare increases the adaptation strategies by $30.3 \%$ (see table 4 ). 
Table 4 Logit regression results to identify the factor influencing for practicing adaptation strategies to the climate change impacts in agriculture in the study area*

\begin{tabular}{l|cccccccc}
\hline \multicolumn{1}{c|}{ Variable } & Coefficients & $\mathrm{Z}$ & $\mathrm{P}>|\mathrm{Z}|$ & $\mathrm{SE}$ & $\mathrm{dy} / \mathrm{dx}{ }^{\mathrm{b}}$ & $\mathrm{S}^{\mathrm{E}} \mathrm{E}^{\mathrm{b}}$ & $\mathrm{Z}^{\mathrm{b}}$ & $\mathrm{p}>|\mathrm{Z}|^{\mathrm{b}}$ \\
\hline Economically active members & 0.193 & 0.92 & 0.357 & 0.209 & 0.043 & 0.48 & 0.9 & 0.366 \\
Education & $1.065^{* *}$ & 0.88 & 0.038 & 0.744 & 0.314 & 0.016 & 0.88 & 0.037 \\
Farm size & 0.293 & 2.13 & 0.578 & 1.077 & 0.303 & 0.143 & 2.12 & 0.114 \\
Annual cash earning & 0.512 & 1.43 & 0.038 & 0.015 & 0.015 & 0.001 & 2.82 & 0.146 \\
Credit & 0.802 & 1.21 & 0.225 & 0.662 & 0.175 & 0.139 & 1.26 & 0.208 \\
Training/extension & $3.730^{* * *}$ & 4.32 & 0.000 & 0.864 & 0.661 & 0.90 & 7.29 & 0.000 \\
Constant & -0.709 & 0.65 & 0.000 & 1.091 & - & - & & \\
\hline
\end{tabular}

*Source: Field Survey, 2012; SE: Standard error

Access to credit:This variable also has a positive coefficient implying that access to credit has a strong influence on farmers' decisions to adapt to climate change. If a farmer has access to credit then his/her probability of adapting to climate change increases by about 54\% (See Table 4). Farmers that have access to credit in Nawalparsi district have a predicted probability of 0.225 of adapting to climate change. More financial resources allow the farmer to change their farming practices in response to changes in climate change. Most farmers in Nawalparasi derive their livelihoods on subsistence farming. These results are in line with the finding of Fosu-Mensah et al., (2010) who found access to credit as critical in helping farmers to adapt to climate change in Africa.

Training and extension:Training and extension is statistically significant at $1 \%$ level of significance as shown by a p-value of 0.000 . If a farmer is exposed to information on climate change then his/her probability of adaptation to climate change increases by about $66.1 \%$ (see table 4). This implies that more climate change information dissemination through extension services, weather reports and other channels increase the likelihood of farmers to adapt the climate change. These results could be explained by the fact that farmers in Nawlparasi are to some extent exposed to climate change information through extension services although these could be intensified to increase the adaptation rate in the district. The results are consistent with findings of Deressa (2009) who found information on climate change as significant in influencing farmers' adaptation choice.

Annual cash earning: Annnual cash earning though the variable is not significant, it has positive coefficient too implying that each unit increase in the annual cash earnings increases the probability of practicing different adaptation strategies by $1.5 \%$ (see table 4 ). This implies that the greater the annual cash earning greater will be the probabilities of practicing adaptation strategies. This result is similar to the result found by Ramison, 2006.

\section{Conclusions}

Agriculture is the source of livelihood for more than $65.6 \%$ of people in Nepal. Nepalese agriculture is heavily dependent upon the nature, so occurrences of any alteration in the climatic variables affect seriously on it. Farmers depending on subsistence agriculture for their livelihood have been greatly affected by the changing climate and climatic variability. A sample of 90 households from each of VDC namely Deurali and Agyouli were randomly selected, thus a total of 180 respondents constituted the sample size. Primary data were collected from interview through structured and unstructured questionnaires. The study was conducted to find out the determinants of farmers adaptation to climate change in Nawalparasi district of Nepal.

Crop diversification, zero tillage,mulching, water harvesting, plastic tunnelling, use of mulching and composting of weeds to control loss and conserving moisture are some of the practices adapted by the farming communities to cope with the changing climate.

Logit regression analysis shows that education and training and extension by different governmental and nongovernmental organizations were the significant variables to practice different stronger adaptation strategies by the farmers. A unit increase in schooling year and provision of training-extension increases the probability of practicing different adaptation strategies by $31 \%, 66 \%$.

Farmers have been using their knowledge and experience in implementing adaptation measures at local level. Farmers have adopted both agricultural and non agricultural adaptations. So, it is important to plan sustainable adaptation strategies based on scientific research and make farmers prepared to cope with the increasing impacts of climate change in coming days.

Table 5 Summary statistics*

\begin{tabular}{l|l}
\hline Number of observation(N) & 180 \\
\hline Log likelihood & -33.035 \\
LR $\operatorname{chi}^{2}(6)$ & $42.37\left(\right.$ Prob $\left.>\mathrm{chi}^{2}=0.000\right)$ \\
Pseudo $\mathrm{R}^{2}$ & 0.39 \\
\hline
\end{tabular}

*Source: Field Survey, 2012

\section{Acknowledgement}

Author want to extend sincere gratitude to Practical Action, Nepal which support for this study and would like to express sincere gratitude to IAAS Rampur, Chitwan for their help. Sincere thanks goes to respondents of Deurali and Agyouli V.D.Cs.

\section{References}

Abrol Y, Ingram K. 1996. Effects of higher day and night temperatures on growth and yields of some crop plants. In F. Bazzaz, \& W. Sombroek (Eds). Global climate change and agricultural production: Direct and indirect effects of changing hydrological, pedological and plant physiologicalprocesses, 123140. John Wiley \& Sons Ltd, West Sussex, England. 
Al-Karablieh E, Ahmad A, Hunaiti D. 2009. Logit Models for Identifying the Factors that Influence the Adoption of Barley Production Technologies in Low Rainfall Areas. Jordan Journal of Agricultural Science. 5: 251-265.

Apata T, Samuel K. 2009. Analysis of Climate Change Perception and Adaptation among Arable Food Crop Farmers in South Western Nigeria. Journal of Climate change and Adaptation. 4: 12-14.

Aris D. 2010. Farmers' perception on adaptation to climate change: A case study of irrigators in the River land, South Australia, Wageningen University Press, The Netherlands.

Deressa T, Hassan R, Ringler C. 2009. Determinants of Farmers' choice of adaptation methods to Climate change in the Nile Basin of Ethiopia. Global Environmental Change. 19: 248-255.

Deressa T, Hassan R, Ringler, C. 2010. Perception and Adaptation toClimate Change: The Case of Farmers in the Nile Basin of Ethiopia, The Journal of Agricultural Science.149: 23-31.

Food and Agriculture Organisation 2008. Climate Change Adaptation And Mitigation In The Food and Agriculture Sector, Technical Background Document FromThe Expert Consultation.

Fosu-Mensah B, Vlek P, Manschadi A. 2010. Farmers' Perceptions and Adaption to climate Change. A Case Study of Sekyedumase District in Ghana. Centre for Development Research, University of Bonn. 11: 20-30.

Gbetibouo G. 2009. Understanding Farmers' Perception and Adaptations to climate change and Variability,: International Food Policy Research Institute, Washington, DC.
Gunjal K. 2008. Crop And Food SupplyAssessment Mission To Zimbabwe, Food and Agriculture Organisation/World Food Programme.

Hosmer D, Lemeshew S. 1989. Applied Logistic Regression. A Wiley-Inter ISBN 1-920160-01-09.

Kalyebara R. 1999. A comparison of factors affecting adoption of improved coffee management recommendations between small and larger farmers in Jordan. Jordan journal of Agricultural sciences. 5: 45-67.

Maharjan K, Joshi N, Piya L. 2009. Sources of climate change, its impact, and mitigation issues in Nepal.International Conference on Climate Change, Livelihoods, and Food security. Jaipur, India. Institute of Development Studies.

MOPE. 2000. Implementation of UN Convention to Control Desertification. Ministry of Population and Environment, HMG Nepal, Kathmandu.

Ramison D. 2006. The Perception and Adaptation to Climate Change in Africa,CEEPA Discussion Paper No. 10 Special Series on Climate Change and Agriculture in Africa science Publication, New York.

Schmidhuber J, Tubiello, F. 2007. Global food security under climate change. Proceedings of the National Academy of Science (PNAS), 104(50), 19703-19708.

Seo S, Mendelsohn R. 2006. Climate Change Adaptation In Africa: A Microscopic Analysis Of Livestock Choice. 5: 20-30.

Shrestha B, Wake C, Mayewski P, Dibbl J. 1999. Maximum temperature trends in the Himalaya and its vicinity. An analysis based on temperature records from Nepal. 12: 277-278.

Smit B, Burton I. 1999. The Science of Adaptation: A Framework for Assessment. Mitigation and Adaptation Strategies for Global Change. 4: 199-213. 